\title{
Allometric equations for pioneer tree species and estimation of the aboveground biomass of a tropical secondary forest in East Kalimantan
}

\author{
Toru Hashimoto $^{1)}$, Takeshi TAngE ${ }^{2)}$, Masaya MASUmori ${ }^{2)}$, Hisayoshi YAgI $^{3)}$, Satohiko SASAKI ${ }^{4)}$, and Katsumi KoJima ${ }^{5)}$ \\ ${ }^{1)}$ Tohoku Research Center, Forestry and Forest Products Research Institute, Morioka, Iwate 020-0123, Japan. \\ ${ }^{2)}$ Graduate School of Agricultural and Life Sciences, University of Tokyo, Bunkyo-ku, Tokyo 113-8657, Japan. \\ ${ }^{3)}$ Faculty of Bioresources, Mie University, Tsu, Mie 514-8507, Japan. \\ ${ }^{4)}$ College of Bioresource Sciences, Nihon University, Fujisawa, Kanagawa 252-8510, Japan. \\ 5) Asian Natural Environmental Science Center, University of Tokyo, Bunkyo-ku, Tokyo 113-8657, Japan.
}

\begin{abstract}
To estimate the aboveground biomass of tropical secondary forests dominated by pioneer species, allometric equations to relate diameter at breast height with the dry mass of the aboveground organs of several pioneer species were developed. The aboveground biomass of secondary forests was estimated using four methods based on the allometric equations. Biomass estimated with an allometric equation for all species combined was equivalent to that estimated with species-specific allometric equations. However, the estimated biomass based on a general-purpose allometric equation was substantially higher than that using other allometric equations. The allometric equation for all species combined is suitable for estimating the biomass of a secondary forest from the view points of accuracy and labor.
\end{abstract}

Key words: biomass estimation, East Kalimantan, pioneer species, fallow forest

\section{INTRODUCTION}

The estimation of aboveground biomass is an essential tool for evaluating the productivity and nutrient cycling of forests. As well, the recent studies on global climate change have highlighted the role of forests as carbon sinks. Changes in the cover, utilization, and management of forests all affect the exchange of carbon between terrestrial ecosystems and the atmosphere (Bolin et al., 2000). To assess the role of forests as carbon sinks and sources, an accurate means of estimating forest biomass must be developed.

Tropical forests are a particular concern because they are undergoing significant change, and there are few reliable biomass estimates for these forests (Brown, 1997). In addition, tropical forests have the greatest potential to serve as sinks for carbon dioxide if appropriately managed (Brown et al., 1996). The biomass dynamics of secondary forests, such as fallow forests, are of special interest, because such forests are spreading rapidly as a result of forest degradation in the tropics. For these reasons, we need an efficient and accurate means of biomass estimation for secondary forests composed mainly of pioneer species. With biomass estimations the magnitude of the sources and sinks in these forests can be evaluated and the role of secondary tropical forests in the global carbon cycle will be better understood.

Aboveground biomass can be measured with two common methods. Weighing tree biomass in the field is the most accurate approach, but is destructive and laborious, and is thus generally limited to small areas. In contrast, a method using allometric relationships between tree dimensions and aboveground biomass is more cost-effective. Moreover, welldeveloped allometric equations can estimate forest biomass of other stands easily and non-destructively. Species-specific equations should be used, because trees of different species can differ greatly in tree architecture and wood density (Shukla and Ramakrishnan, 1986; Vester and Cleef, 1998; Castro-Diez et al., 1998). However, it can be very difficult to develop species-specific equations for each species in most primary tropical rainforests because enormous numbers of tree species usually grow in these forests. Since secondary forests are often dominated by only small numbers of pioneer species, it is much easier to develop species-specific equations. Because the wood densities of pioneer species are usually low, allometric equations for these species may differ significantly from those for species with a higher wood density.

In the present study, the development of allometric equations for several tropical pioneer tree species in East Kalimantan, Indonesia is discussed. By means of these equations, the aboveground biomass of secondary forests dominated by pioneer species was estimated using four methods, and the accuracy of each method was evaluated. 


\section{Study area}

METHODS

The study area was Sebulu, East Kalimantan, in the Indonesian part of Borneo ( $0^{\circ} 16^{\prime} \mathrm{S}, 116^{\circ} 59^{\prime} \mathrm{E}$, about $130 \mathrm{~m}$ asl). For our study, we selected forests on a low, undulating plateau with some small rivers and shallow basins. This topography is common in the lowlands of East Kalimantan. The geology of the study area is characterized by Tertiary sedimentary rocks of various textures (Ohta et al., 2000), and the soils are classified mainly as ultisols. From 1993 to 1997, the annual rainfall averaged about $1800 \mathrm{~mm}$, and the mean temperature averaged approximately $28{ }^{\circ} \mathrm{C}$. There used to be dipterocarp forests with aboveground biomass of 509 t/ha (Yamakura et al., 1986a) in this area. Selected logging was carried out in the 1970s. These forests also experienced large-scale forest fires twice: onece between 1982-83 (Malingreau et al., 1985) and again in 1997-98 (Mori, 2000); most plants were lost in the first fire. After those fires, illegal logging and shifting cultivation spread widely throughout the burned area. The deforested lands subsequently became either secondary forests of pioneer species or alang-alang (Imperata cylindrica [L.] Beauv.) grasslands.

\section{Field measurements and data analysis}

Sixteen plots $(10 \mathrm{~m} \times 10 \mathrm{~m})$ in fallow forests were established from June 1993 to October 1994. Each plot was dominated by no more than six species. The three most abundant species in most plots were a Ficus sp., Geunsia pentandra (Roxb.) Merr., and Piper aduncum L. (Hashimoto et al., 2000). All individual trees with a girth at breast height (GBH) $\geq 10 \mathrm{~cm}$ were identified, and their GBH was converted to the diameter at breast height (DBH). Some upper story trees $(\mathrm{GBH} \geq 10 \mathrm{~cm})$ of each species with a range of sizes in each plot were selected, as follows:

1) If there were fewer than six trees of a species in the plot, 1 or 2 trees were sampled.

2) If there were 6 to 30 trees of a species in the plot, 3 trees were sampled.

3) If there were more than 30 trees of a species in the plot, about $10 \%$ of the trees were sampled.

These sample trees were felled at ground level and separated into two parts: assimilative organs (leaves) and nonassimilative organs (stems and branches). Then the fresh weight of each part was determined. Samples from each part were weighed, and then oven-dried at $80{ }^{\circ} \mathrm{C}$ for $48 \mathrm{~h}$ and weighed again to calculate the ratio of fresh weight to dry weight. Trees with $\mathrm{GBH}<10 \mathrm{~cm}$ and all herbaceous plants were also cut and weighed. Samples taken from each plant part were also ovendried at $80{ }^{\circ} \mathrm{C}$ for $48 \mathrm{~h}$ and weighed to calculate the ratio of fresh weight to dry weight.

For each tree species, the allometric relationship between $\mathrm{DBH}$ and total dry weight of the aboveground organs $\left(W_{\mathrm{t}}\right)$, as well as between $\mathrm{DBH}$ and the dry weights of stems and branches $\left(W_{\mathrm{sb}}\right)$ and of leaves $\left(W_{1}\right)$ were separately analyzed, through regressions of logarithmically transformed variates. These variates often satisfy an allometric equation of the following form:

$$
\ln (W)=a \times \ln (\mathrm{DBH})+b
$$

Equation 1

where $W$ is either of $W_{\mathrm{t}}, W_{\mathrm{sb}}$ or $W_{\mathrm{l}}$, and $a$ and $b$ are coefficients.

Because none of the variates were independent of the others, a geometric mean regression line was used to describe the relationship between DBH and the variates (Ricker, 1984). For each tree species, the values of $a$ and $b$ in equation 1 were estimated using the actual weight values obtained by destructive sampling.

The biomass of the 16 sample plots was estimated using four methods:

Method 1: Allometric equations for the relationship between DBH and $W_{\mathrm{sb}}$ and between $\mathrm{DBH}$ and $W_{1}$ for each species in each plot were developed. (For species with only two samples, equations that linked the two points on the DBH $-W_{\mathrm{sb}}$ and $\mathrm{DBH}-W_{1}$ graphs were developed. For those with only one sample, the ratios of DBH to $W_{\mathrm{sb}}$ and of DBH to $W_{1}$ were used.) The aboveground biomass in each plot was estimated by inserting each $\mathrm{DBH}$ value into the allometric equations to generate a weight value, and summing the results. Actual measured weights for the trees we sampled were used directly rather than weights estimated by equation 1 .

Method 2: Allometric equations for the relationship of $\mathrm{DBH}$ to $W_{\mathrm{t}}$ for the three dominant species and others, which include all samples except the three dominant species, were developed from the data for the whole plot. Then the aboveground biomass of each plot was estimated by inserting each $\mathrm{DBH}$ value into the resulting allometric equations to generate a weight value, and summing the results.

Method 3: An allometric equation for the relationship of DBH to $W_{\mathrm{t}}$ was developed from the data for all samples. The aboveground biomass of each plot was estimated by inserting each $\mathrm{DBH}$ value into the allometric equation to generate a weight value, then summing the results.

Method 4: The aboveground biomass of each plot was estimated by inserting each DBH value into the following allometric 
equation:

$$
\ln \left(W_{\mathrm{t}}\right)=2.530 \times \ln (\mathrm{DBH})-2.134
$$

This equation was developed by Brown (1997) to estimate the biomass of trees growing in the moist tropics.

In all the methods, the weights of small plants (except trees with $\mathrm{GBH} \geq 10 \mathrm{~cm}$ ) were added to the weight of upper story trees and the aboveground biomass of each plot was calculated.

ANCOVA was used to test for differences in the regression lines. Differences in the slopes of the allometric lines $(a)$ were tested first. Because there was no significant difference in the value of $a$, interspecific differences in the sampled means of $\ln \left(W_{\mathrm{t}}\right)$ were tested for after adjusting for a common mean of $\ln (\mathrm{DBH})$ and a common slope of the allometric line (Sokal and Rohlf, 1997).

\section{RESULTS AND DISCUSSION}

We obtained 191 datasets for the relationships between $\mathrm{DBH}$ and $W_{\mathrm{sb}}, W_{\mathrm{l}}$, and $W_{\mathrm{t}}$ for the pioneer tree species (Appendices 1-4). From these datasets, we developed allometric equations for the three dominant species, other pioneer tree species, and all species combined (Table 1, Figure 1). Table 1 also includes regression lines for Paraserianthes falcataria (L.) Nielsen in planted forests in the Philippines (Kawahara et al., 1981) and for trees of DBH $\geq 4.5 \mathrm{~cm}$ growing in a natural dipterocarp forest (Yamakura et al., 1986b) in Sebulu for comparison. Both the latter regressions were also performed using a geometric mean regression. The allometric lines for the three dominant pioneer species showed highly significant correlations between $\mathrm{DBH}$ and $W_{\mathrm{t}}\left(r^{2} \geq 0.91\right)$.

Table 1. Estimates of the regression coefficient (a) and intercept (b) for the geometric mean regressions for the three most common species, all other species, and all species combined as follow.

$$
\ln \left(W_{\mathrm{t}}\right)=a \times \ln (\mathrm{DBH})+b \text {, where } W_{\mathrm{t}}=\text { total aboveground biomass }
$$

Entries within column "Adjusted means of $\ln \left(W_{t}\right)$ " not sharing common letters differ significantly at $\mathrm{P}<0.05$ level based on Gabriel's approximate method (Sokal \& Rohlf, 1997), but "All species combined" and "Tropical trees in the moist tropics" are not included in this test.

\begin{tabular}{lccccccc}
\hline & $a$ & $b$ & $\begin{array}{c}\text { Number of } \\
\text { samples }\end{array}$ & $\begin{array}{c}\text { Range of DBH } \\
(\mathrm{cm})\end{array}$ & Adjusted r ${ }^{2}$ & $\begin{array}{c}\text { Adjusted means } \\
\text { of } \ln \left(W_{\mathrm{t}}\right)\end{array}$ \\
\hline $\begin{array}{l}\text { Ficus } \text { sp. } \\
\text { Geunsia pentandra }\end{array}$ & 2.60 & -2.59 & 26 & $3.5-9.1$ & 0.95 & $1.55^{\mathrm{a}}$ \\
$\begin{array}{l}\text { Piper } \text { aduncum } \\
\text { Other species }\end{array}$ & 2.62 & -2.89 & 20 & $3.4-16.2$ & 0.91 & $1.31^{\mathrm{a}}$ \\
All species combined & 2.39 & -2.42 & 37 & $3.2-8.3$ & 0.92 & $1.38^{\mathrm{a}}$ \\
\hline $\begin{array}{l}\text { Paraserianthes falcataria } \\
\text { (Kawahara } \text { et al., 1981) }\end{array}$ & 2.40 & -2.49 & 108 & $3.2-20.3$ & 0.81 & $1.36^{\mathrm{a}}$ \\
$\begin{array}{l}\text { Trees in natural dipterocarp forest } \\
\text { (Yamakura } \text { et al., 1986b) }\end{array}$ & 2.44 & -2.51 & 191 & $3.2-20.3$ & 0.85 & \\
$\begin{array}{l}\text { Tropical trees in the moist tropics } \\
\text { (Brown, 1997) }\end{array}$ & 2.56 & -2.95 & 20 & $4.1-36.1$ & 0.98 & $1.25^{\mathrm{a}}$ \\
\hline
\end{tabular}



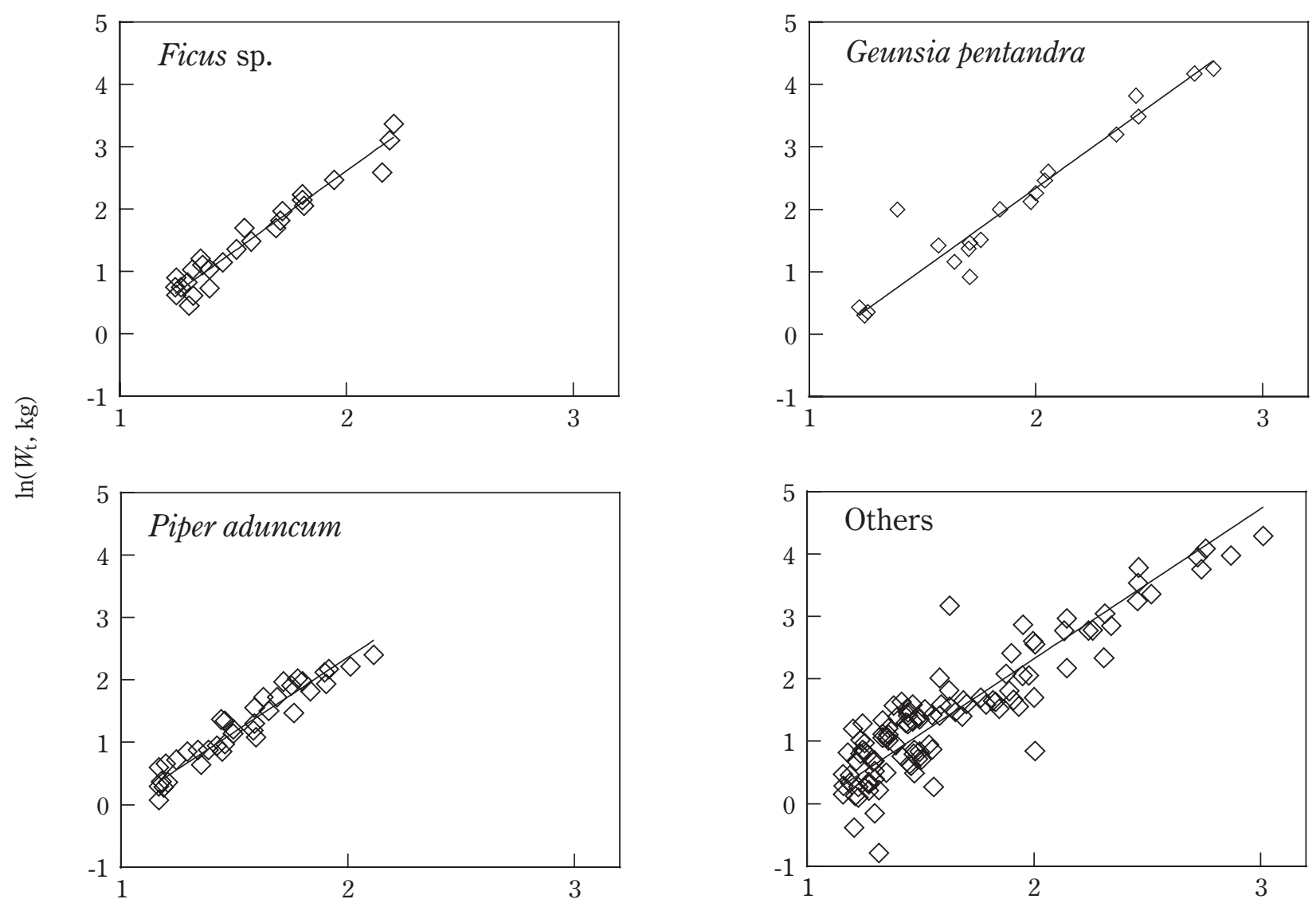

$\ln (\mathrm{DBH}, \mathrm{cm})$

Fig. 1.Geometric mean regression lines for the relationship between $\mathrm{DBH}$ and total aboveground biomass $\left(\mathrm{Wt}_{\mathrm{t}}\right)$

The differences among the allometric lines $(\mathrm{DBH}<10 \mathrm{~cm})$ of the three dominant species, other species, Paraserianthes falcataria and trees in a natural dipterocarp forest were tested with ANCOVA. While there was no difference among the slopes $(a)$ of the allometric lines, there were significant differences among the adjusted means of $\ln \left(W_{\mathrm{t}}\right)$ (Sokal and Rohlf, 1997) (Table 1). The adjusted mean of $\ln \left(W_{\mathrm{t}}\right)$ of trees in a dipterocarp natural forest reported by Yamakura et al. (1986b) was significantly larger than the other values. This result implies that the tree architecture and wood density did not differ significantly among the pioneer species, but clearly differed between pioneer and climax species. Specific gravity of Geunsia pentandra is 0.43 (Seng, 1951), and specific density of Piper adunucum is $0.475 \mathrm{~g} / \mathrm{cm}^{3}$ (López et al., 2002). On the other hand, the specific gravities of the dominant species in the natural dipterocarp forest (Sukardjo et al., 1990) are larger, 0.92 (Dipterocarp crinitus Dyer; No. 2 of basal area ranking in the study of Sukardjo et al., 1990), 0.71 (Hopea mengarawan Miq.; No. 3), 0.99 (Shorea laevis Ridl.; No.4) (Seng, 1951). These differences in specific gravity may cause the differences in adjusted means of allometric line. The allometric line of Brown (1997) was not included in our ANCOVA, because their data comprised several different study sites, including that of Yamakura et al. (1986b) and some unpublished data.

Using the allometric equations we derived and that of Brown (1997), the aboveground biomass for each of our 16 plots was calculated. Using the species-specific allometry (Method 1), it was estimated that the aboveground biomass ranged between 8 and $57 \mathrm{t} / \mathrm{ha}$. Because all plants were not harvested, the true aboveground biomass could not be estimated. It is desirable to make allometric equations for not only each species, but also for each stand, to estimate accurate biomass, because the differences in stand density may affect allometric relations. In doing that, however, there is some possibility that the estimation error may increase since the sample number of each species would decrease to make each allometric equation. For instance, the ratios of $\mathrm{DBH}$ to $W_{\mathrm{sb}}$ and of $\mathrm{DBH}$ to $W_{1}$ were used for only an individual sample in Method 1. However, because the errors due to small sample size seemed negligible for most species, which had a considerable number of samples, the estimates by Method 1 are regarded as the most accurate ones. The values estimated by Methods $2-4$ were 
compared to those by Method 1 . The differences between methods were expressed as the average of

|Method 1 - Method $(2,3,4) \mid /$ Method 1

of each plot. The aboveground biomass calculated using Methods 2 and 3 both differed by about $13 \%$ from the values calculated using Method 1 (Fig. 2). There was no significant difference between the calculated values using Methods 2 and 3 , because the differences in the allometric equations for the three dominant pioneers and for the other species were not significant. However, values calculated using Method 4 were about $54 \%$ greater than those calculated using Method 1.

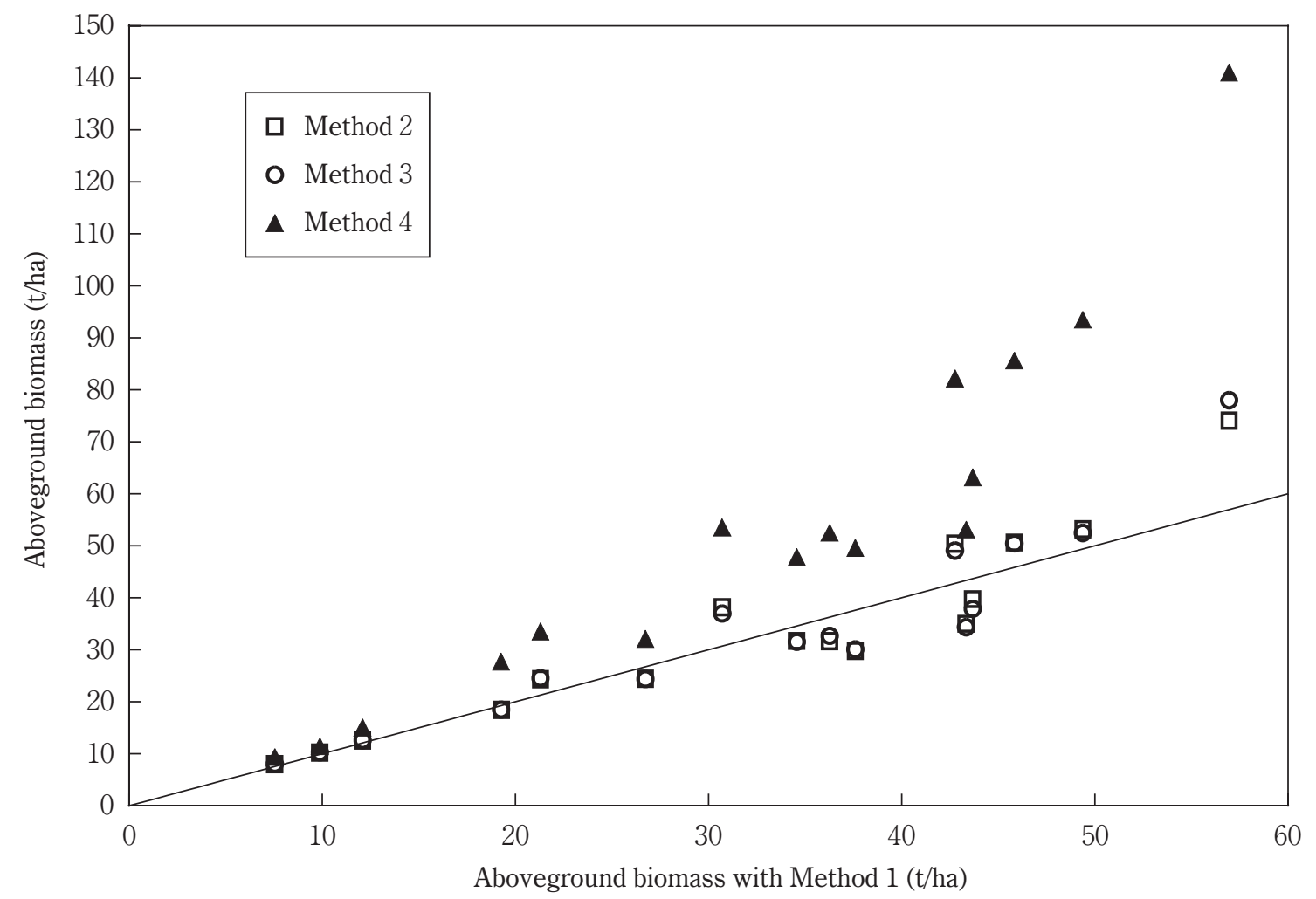

Fig. 2. Calculation of total aboveground biomass of a secondary forest with three estimation methods (Methods 2, 3, and 4) compared with the value for Method 1 (based on species-specific allometry)

In estimating the aboveground biomass of secondary forests dominated by pioneer species, it is possible that generalpurpose allometric equations may lead to overestimates, however those equations may be very useful to estimate forest biomass on a global scale. In conclusion, allometric equations for all species combined are most suitable for estimating the total aboveground biomass of secondary forests dominated by pioneer species that have regenerated after shifting cultivation. These equations offer moderate accuracy, and produce estimates with far less labor than in approaches based on species-specific sampling.

This study showed the usefulness of the species-pooled allometric equation for the estimation of the above ground biomass of the study forests. Further clarification on the applicability of species-pooled equations to tropical secondary forests in other regions and with different pioneer species is still required.

ACKNOWLEDGEMENTS This research was supported in part by Sumitomo Forestry Co., Ltd., and by the Japan International Forestry Promotion and Cooperation Center. 


\section{REFERENCES}

Bolin, B., Sukumar, R., Ciais, P., Cramer, W., Jarvis, P., Kheshgi, H., Nobre, C., Semenov, S. \& Steffen, W. 2000. Global perspective. In: Land use, land-use change, and forestry. (Watson, R. T., Noble, I. R., Bolin, B., Ravindranath, N. H., Verardo, D. J. \& Dokken, D. J. eds.), Pp. 23 - 51. Cambridge University Press, Cambridge.

Brown, S. 1997. Estimating biomass and biomass change of tropical forests. FAO Forestry Paper 134. FAO, Rome. 55 pp.

Brown, S., Sathaye, J., Cannell, M. \& Kauppi, P. 1996. Mitigation of carbon emissions to the atmosphere by forest management. Commonwealth Forestry Review 75: 80 - 91.

Castro-Díez, P., Puyravaud, J. P., Cornelissen, J. H. C. \& Villar-Salvador, P. 1998. Stem anatomy and relative growth rate in seedlings of a wide range of woody plant species and types. Oecologia 116: 57 - 66.

Hashimoto, T., Kojima, K., Tange, T. \& Sasaki, S. 2000. Changes in carbon storage in fallow forests in the tropical lowlands of Borneo. Forest Ecology and Management 126: 331 - 337.

Kawahara, T., Kanazawa, Y. \& Sakurai, S. 1981. Biomass and net production of man-made forests in the Philippines. Journal of the Japanese Forestry Society 63: 320 - 327.

López, M., de Koning, F., Paredes, H. \& Benítez, P. 2002. Estimación de carbono en biomasa de bosques secundarios y plantaciones forestales en el Noroccidente de Ecuador. Deutsche Gesellschaft für Technische Zusammenarbeit (GTZ) $\mathrm{GmbH}$, Eschnorn, Alemania. p15.

Malingreau, J. P., Stephens, G. \& Fellows, L. 1985. Remote sensing of forest fires: Kalimantan and North Borneo in 1982 83. Ambio 14: 314 - 321.

Mori, T. 2000. Effects of droughts and forest fires on dipterocarp forest in East Kalimantan. In: Rainforest ecosystems of East Kalimantan. (Guhardja, E., Fatawi, M., Sutisna, M., Mori, T. and Ohta, S. eds.), Pp. 29 - 45. Springer - Verlag, Tokyo.

Ohta, S., Morisada, K., Tanaka, N., Kiyono, Y. \& Effendi, S. 2000. Are soils in degraded dipterocarp forest ecosystems deteriorated? A comparison of Imperata grasslands, degraded secondary forests, and primary forests. In: (Guhardja, E., Fatawi, M., Sutisna, M., Mori, T. \& Ohta, S. eds). Rainforest ecosystems of East Kalimantan, 49 - 57. Springer - Verlag, Tokyo.

Ricker, W. E. 1984. Computation and uses of central trend lines. Canadian Journal of Zoology 62: 1897 - 1905.

Seng, O. D. 1951. Perbandingan berat dari djenis ${ }^{2}$ kaju Indonesia dan pengartian beratnja kaju untuk keperluan praktek - De soortelijke gewichten van Indonesische houtsoorten en hun betekenis voor de praktijk -. Balai Penjelidikan Kehutanan, Bogor, Indonesia. 183 pp.

Sekardjo, S., Hagihara, A., Yamakura, T. \& Ogawa, H. 1990. Floristic composition of tropical rain forest in Indonesian Borneo. Bull. Nagoya Univ. For. 10: 1 - 44.

Shukla, R. P. \& Ramakrishnan, P. S. 1986. Architecture and growth strategies of tropical trees in relation to successional status. Journal of Ecology 74: 33 - 46.

Sokal, R. R. \& Rohlf, F. J. 1997. Biometry: the principles and practice of statistics in biological research. 3rd edition. W. H. Freeman and Company, New York, 887 pp.

Vester, H. F. M. \& Cleef, A. M. 1998. Tree architecture and secondary tropical rain forest development - A case study in Araracuara, Colombian Amazonia. Flora 193: 75 - 97.

Yamakura, T., Hagihara, A., Sukardjo, S. \& Ogawa, H. 1986a. Aboveground biomass of tropical rain forest stands in Indonesian Borneo. Vegetatio 68: 71 - 82.

Yamakura, T., Hagihara, A., Sukardjo, S. \& Ogawa, H. 1986b. Tree size in a mature dipterocarp forest stand in Sebulu, East Kalimantan, Indonesia. Southeast Asian Studies 23: 452 - 478.

Received $20^{\text {th }}$ Nov. 2003

Accepted $11^{\text {th }}$ June 2004 
Appendix 1. Dry weight of the aboveground organs of Ficus sp.

\begin{tabular}{|c|c|c|c|c|}
\hline Plot No. & $\mathrm{GBH}(\mathrm{cm})$ & $W 1(\mathrm{~kg})$ & $W \mathrm{sb}(\mathrm{kg})$ & Total (kg) \\
\hline 1 & 19.1 & 0.93 & 8.40 & 9.32 \\
\hline 1 & 17.0 & 0.57 & 4.88 & 5.44 \\
\hline 1 & 11.5 & 0.24 & 2.04 & 2.28 \\
\hline 2 & 11.2 & 0.17 & 1.95 & 2.11 \\
\hline 2 & 12.7 & 0.26 & 2.55 & 2.82 \\
\hline 2 & 14.3 & 0.30 & 3.57 & 3.87 \\
\hline 3 & 11.8 & 0.23 & 2.55 & 2.78 \\
\hline 3 & 17.5 & 0.51 & 6.63 & 7.14 \\
\hline 3 & 22.0 & 0.96 & 10.79 & 11.76 \\
\hline 4 & 12.2 & 0.31 & 3.02 & 3.33 \\
\hline 4 & 12.7 & 0.24 & 1.83 & 2.07 \\
\hline 6 & 12.3 & 0.32 & 2.68 & 3.00 \\
\hline 6 & 11.8 & 0.17 & 1.68 & 1.85 \\
\hline 7 & 19.1 & 1.41 & 7.12 & 8.53 \\
\hline 7 & 14.8 & 0.76 & 4.68 & 5.44 \\
\hline 7 & 11.0 & 0.33 & 2.12 & 2.45 \\
\hline 8 & 28.1 & 3.48 & 18.70 & 22.18 \\
\hline 9 & 15.3 & 0.40 & 4.00 & 4.39 \\
\hline 9 & 19.3 & 0.74 & 7.04 & 7.79 \\
\hline 9 & 10.9 & 0.09 & 2.03 & 2.12 \\
\hline 10 & 13.5 & 0.17 & 2.98 & 3.15 \\
\hline 10 & 17.4 & 0.32 & 5.83 & 6.15 \\
\hline 10 & 27.2 & 0.73 & 12.51 & 13.25 \\
\hline 15 & 11.0 & 0.07 & 1.78 & 1.85 \\
\hline 15 & 28.6 & 3.47 & 25.32 & 28.79 \\
\hline 16 & 11.6 & 0.19 & 1.38 & 1.57 \\
\hline
\end{tabular}

1) GBH: Girth at breast height

2) $W_{\text {I: }}$ Dry weight of leaves

3) $W$ sb: Dry weight of stems and branches

Appendix 2. Dry weight of the aboveground organs of Geunsia pentandra

\begin{tabular}{crrrr}
\hline Plot No. & GBH $(\mathrm{cm})$ & $W$ l $(\mathrm{kg})$ & $W$ sb $(\mathrm{kg})$ & Total $(\mathrm{kg})$ \\
\hline 2 & 10.7 & 0.15 & 1.39 & 1.53 \\
2 & 17.3 & 0.56 & 3.36 & 3.92 \\
2 & 23.2 & 1.45 & 8.12 & 9.58 \\
3 & 50.8 & 4.85 & 65.58 & 70.43 \\
3 & 17.4 & 0.02 & 2.47 & 2.50 \\
4 & 16.2 & 0.10 & 3.08 & 3.19 \\
4 & 36.5 & 1.91 & 30.74 & 32.65 \\
6 & 24.5 & 1.85 & 11.62 & 13.47 \\
6 & 18.2 & 0.68 & 3.84 & 4.53 \\
6 & 10.9 & 0.02 & 1.33 & 1.35 \\
7 & 22.7 & 1.04 & 7.30 & 8.34 \\
7 & 17.4 & 0.40 & 3.92 & 4.32 \\
8 & 36.1 & $12.25 *$ & 33.35 & 45.59 \\
9 & 24.2 & 1.37 & 10.36 & 11.73 \\
9 & 12.6 & 0.65 & 6.70 & 7.36 \\
9 & 46.7 & 5.61 & 59.30 & 64.91 \\
10 & 15.1 & 0.14 & 4.00 & 4.13 \\
10 & 19.8 & 0.45 & 6.93 & 7.38 \\
15 & 33.1 & 3.00 & 21.51 & 24.51 \\
15 & 11.1 & 0.03 & 1.40 & 1.43 \\
\hline 10 & & & &
\end{tabular}

1) GBH: Girth at breast height

2) $W_{\text {l: }}$ Dry weight of leaves

3) $W_{\mathrm{sb}}$ : Dry weight of stems and branches

* An obviously anomalous value, possibly caused by measurement error.
Appendix 3. Dry weight of the aboveground organs of Piper aduncum

\begin{tabular}{|c|c|c|c|c|}
\hline Plot No. & $\mathrm{GBH}(\mathrm{cm})$ & $W \mathrm{l}(\mathrm{kg})$ & $W \mathrm{sb}(\mathrm{kg})$ & Total (kg) \\
\hline 3 & 11.5 & 0.15 & 2.19 & 2.34 \\
\hline 3 & 16.0 & 0.31 & 5.28 & 5.58 \\
\hline 4 & 13.1 & 0.11 & 2.46 & 2.57 \\
\hline 4 & 10.2 & 0.04 & 1.41 & 1.45 \\
\hline 6 & 14.0 & 0.26 & 3.09 & 3.35 \\
\hline 6 & 15.5 & 0.17 & 2.77 & 2.94 \\
\hline 6 & 10.1 & 0.21 & 1.60 & 1.82 \\
\hline 7 & 10.1 & 0.14 & 0.94 & 1.08 \\
\hline 7 & 14.0 & 0.24 & 2.87 & 3.12 \\
\hline 7 & 12.6 & 0.18 & 2.22 & 2.40 \\
\hline 8 & 12.0 & 0.19 & 2.21 & 2.40 \\
\hline 8 & 17.5 & 0.51 & 6.68 & 7.19 \\
\hline 8 & 10.9 & 0.22 & 1.84 & 2.05 \\
\hline 8 & 19.7 & 0.29 & 5.88 & 6.17 \\
\hline 8 & 15.4 & 0.20 & 3.45 & 3.66 \\
\hline 9 & 18.1 & 0.29 & 6.46 & 6.75 \\
\hline 9 & 21.4 & 0.55 & 8.24 & 8.79 \\
\hline 9 & 13.5 & 0.08 & 3.76 & 3.83 \\
\hline 9 & 10.5 & 0.05 & 1.37 & 1.43 \\
\hline 10 & 13.4 & 0.09 & 2.25 & 2.34 \\
\hline 10 & 19.0 & 0.24 & 7.00 & 7.24 \\
\hline 10 & 21.1 & 0.31 & 6.61 & 6.91 \\
\hline 12 & 10.3 & 0.11 & 1.21 & 1.32 \\
\hline 13 & 10.1 & 0.09 & 1.25 & 1.34 \\
\hline 13 & 13.5 & 0.20 & 2.43 & 2.64 \\
\hline 13 & 15.3 & 0.19 & 3.09 & 3.28 \\
\hline 14 & 15.4 & 0.39 & 4.35 & 4.74 \\
\hline 14 & 18.6 & 0.61 & 6.95 & 7.55 \\
\hline 14 & 13.3 & 0.28 & 3.63 & 3.91 \\
\hline 14 & 17.0 & 0.47 & 5.13 & 5.60 \\
\hline 15 & 26.1 & 0.25 & 10.79 & 11.04 \\
\hline 15 & 23.5 & 0.33 & 8.82 & 9.15 \\
\hline 15 & 18.3 & 0.07 & 4.28 & 4.34 \\
\hline 15 & 21.0 & 0.31 & 8.04 & 8.36 \\
\hline 15 & 12.2 & 0.11 & 1.78 & 1.89 \\
\hline 16 & 10.4 & 0.09 & 1.83 & 1.92 \\
\hline 16 & 16.4 & 0.34 & 4.16 & 4.50 \\
\hline
\end{tabular}

1) GBH: Girth at breast height

$W_{1}$ : Dry weight of leaves

3) $W_{\mathrm{sb}}$ : Dry weight of stems and branches 
Appendix 4. Dry weight of the aboveground organs of other pioneer species

\begin{tabular}{|c|c|c|c|c|c|c|c|c|c|c|c|}
\hline Species name & Plot No. & $\mathrm{GBH}(\mathrm{cm})$ & $W l(\mathrm{~kg})$ & $W \mathrm{sb}(\mathrm{kg})$ & Total (kg) & Species name & Plot No. & $\mathrm{GBH}(\mathrm{cm})$ & $W \mathrm{l}(\mathrm{kg})$ & $W \mathrm{sb}(\mathrm{kg})$ & Total (kg) \\
\hline Artocarpus sp. & 7 & 31.6 & 2.13 & 8.21 & 10.35 & Mallotus sp. & 14 & 13.2 & 0.18 & 3.48 & 3.65 \\
\hline Blumea sp. & 3 & 10.5 & 0.02 & 0.66 & 0.68 & Mallotus sp. & 14 & 20.8 & 0.32 & 5.76 & 6.08 \\
\hline Bridelia sp. & 7 & 23.1 & 2.14 & 11.36 & 13.50 & Melastoma malabathricum & $n \quad 2$ & 11.5 & 0.08 & 1.90 & 1.99 \\
\hline Cratoxylon arborescens & 2 & 12.5 & 0.58 & 4.23 & 4.81 & Melastoma malabathricum & 2 & 10.9 & 0.24 & 3.37 & 3.61 \\
\hline Dysoxylon sp. & 13 & 14.0 & 0.37 & 3.61 & 3.98 & Melastoma malabathricum & 2 & 13.3 & 0.30 & 4.28 & 4.58 \\
\hline Dysoxylon sp. & 13 & 12.2 & 0.31 & 2.58 & 2.89 & Melastoma malabathricum & 6 & 12.2 & 0.17 & 2.58 & 2.75 \\
\hline Euodia sp. & 7 & 23.3 & 2.99 & 9.90 & 12.89 & Melastoma malabathricum & 6 & 10.2 & 0.14 & 2.13 & 2.27 \\
\hline Euodia sp. & 1 & 11.5 & 0.26 & 1.42 & 1.68 & Melastoma malabathricum & 7 & 13.6 & 0.33 & 4.58 & 4.91 \\
\hline Euodia sp. & 1 & 18.8 & 0.75 & 4.14 & 4.90 & Melastoma malabathricum & 7 & 10.5 & 0.15 & 3.17 & 3.32 \\
\hline Euodia sp. & 1 & 23.3 & 1.39 & 0.94 & 2.32 & Melastoma malabathricum & $n \quad 13$ & 12.7 & 0.27 & 3.76 & 4.03 \\
\hline Euodia sp. & 2 & 11.5 & 0.44 & 1.04 & 1.49 & Melastoma malabathricum & $n \quad 8$ & 13.6 & 0.05 & 3.68 & 3.73 \\
\hline Euodia sp. & 13 & 13.7 & 0.30 & 1.92 & 2.22 & Nauclea sp. & 7 & 16.0 & 4.92 & 18.95 & 23.87 \\
\hline Euodia sp. & 13 & 14.2 & 0.36 & 1.68 & 2.03 & Nauclea sp. & 16 & 10.8 & 0.33 & 1.89 & 2.22 \\
\hline Fordia sp. & 1 & 11.9 & 1.22 & 2.58 & 3.80 & Nauclea sp. & 16 & 17.0 & 0.50 & 4.72 & 5.21 \\
\hline Fordia sp. & 8 & 11.0 & 0.43 & 1.87 & 2.31 & Nauclea sp. & 16 & 20.5 & 1.02 & 6.99 & 8.01 \\
\hline Fordia sp. & 8 & 11.9 & 0.86 & 2.19 & 3.04 & Nauclea sp. & 16 & 26.8 & 1.96 & 17.46 & 19.41 \\
\hline Fordia sp. & 8 & 13.3 & 0.94 & 3.17 & 4.11 & Poikilospermum sp. & 10 & 14.9 & 0.02 & 1.29 & 1.31 \\
\hline Fordia sp. & 8 & 22.1 & 3.78 & 13.85 & 17.63 & Pterospermum javanicum & 15 & 36.8 & 4.81 & 39.20 & 44.01 \\
\hline Fordia sp. & 8 & 15.3 & 1.46 & 6.04 & 7.51 & Trema orientalis & 13 & 13.9 & 0.20 & 1.86 & 2.05 \\
\hline Fordia sp. & 9 & 13.0 & 1.17 & 3.94 & 5.12 & Trema orientalis & 13 & 13.5 & 0.18 & 1.65 & 1.83 \\
\hline Helisia sp. & 4 & 10.6 & 0.14 & 1.84 & 1.98 & Trema orientalis & 13 & 10.6 & 0.06 & 1.07 & 1.13 \\
\hline Leucosyke capitelata & 2 & 15.3 & 0.06 & 4.03 & 4.09 & Trema tomentosa & 5 & 11.7 & 0.14 & 1.10 & 1.24 \\
\hline Leucosyke capitelata & 2 & 14.4 & 0.25 & 4.29 & 4.54 & Trema tomentosa & 5 & 14.6 & 0.34 & 2.24 & 2.58 \\
\hline Leucosyke sp. & 14 & 10.8 & 0.37 & 2.40 & 2.77 & Trema tomentosa & 5 & 14.0 & 0.28 & 2.01 & 2.29 \\
\hline Leucosyke sp. & 14 & 12.2 & 0.72 & 2.63 & 3.35 & Trema tomentosa & 5 & 13.7 & 0.26 & 2.10 & 2.36 \\
\hline Macaranga gigantea & 3 & 26.8 & 0.53 & 8.25 & 8.78 & Trema tomentosa & 5 & 10.7 & 0.19 & 1.12 & 1.31 \\
\hline Macaranga gigantea & 4 & 55.3 & 6.59 & 46.82 & 53.41 & Trema tomentosa & 5 & 10.0 & 0.19 & 0.97 & 1.16 \\
\hline Macaranga gigantea & 4 & 48.6 & 3.09 & 39.59 & 42.68 & Trema tomentosa & 5 & 10.0 & 0.23 & 1.10 & 1.33 \\
\hline Macaranga gigantea & 4 & 19.9 & 0.44 & 4.14 & 4.58 & Trema tomentosa & 5 & 11.2 & 0.16 & 1.08 & 1.24 \\
\hline Macaranga sp. 1 & 3 & 38.9 & 2.74 & 26.05 & 28.79 & Trema tomentosa & 11 & 11.5 & 0.13 & 0.73 & 0.86 \\
\hline Macaranga sp. 1 & 15 & 11.7 & 0.01 & 0.45 & 0.45 & Vernonia arborea & 1 & 32.6 & 2.15 & 15.15 & 17.29 \\
\hline Macaranga sp. 1 & 15 & 16.4 & 0.11 & 4.25 & 4.36 & Vernonia arborea & 1 & 21.7 & 0.66 & 4.09 & 4.75 \\
\hline Macaranga sp. 1 & 3 & 49.5 & 5.99 & 53.38 & 59.37 & Sp. 1 & 2 & 12.2 & 0.36 & 2.65 & 3.02 \\
\hline Macaranga sp. 1 & 3 & 22.7 & 0.88 & 6.93 & 7.81 & Sp. 1 & 2 & 11.2 & 0.27 & 1.92 & 2.19 \\
\hline Macaranga sp. 1 & 4 & 22.1 & 0.66 & 7.10 & 7.77 & Sp. 1 & 10 & 21.0 & 0.01 & 11.11 & 11.12 \\
\hline Macaranga sp. 1 & 4 & 63.8 & 2.65 & 70.21 & 72.87 & Sp. 1 & 10 & 14.0 & 0.15 & 3.71 & 3.86 \\
\hline Macaranga sp. 1 & 4 & 47.8 & 3.03 & 48.84 & 51.87 & Sp. 1 & 10 & 16.0 & 0.14 & 5.99 & 6.13 \\
\hline Macaranga sp. 1 & 10 & 19.4 & 0.17 & 5.05 & 5.21 & Sp. 2 & 3 & 14.8 & 0.08 & 4.07 & 4.14 \\
\hline Macaranga sp. 1 & 10 & 31.8 & 2.23 & 18.79 & 21.02 & Sp. 2 & 3 & 10.9 & 0.04 & 2.32 & 2.36 \\
\hline Macaranga sp. 1 & 10 & 30.1 & 1.84 & 14.25 & 16.09 & Sp. 3 & 7 & 29.5 & 1.72 & 14.32 & 16.04 \\
\hline Macaranga sp. 2 & 11 & 12.1 & 0.47 & 1.17 & 1.64 & Sp. 3 & 7 & 36.6 & 3.38 & 22.34 & 25.71 \\
\hline Macaranga sp. 2 & 11 & 11.2 & 0.32 & 1.10 & 1.41 & Sp. 4 & 8 & 15.4 & 0.65 & 4.24 & 4.89 \\
\hline Macaranga sp. 2 & 11 & 11.2 & 0.35 & 1.02 & 1.37 & Sp. 4 & 8 & 13.3 & 0.69 & 3.62 & 4.31 \\
\hline Macaranga sp. 2 & 11 & 10.7 & 0.25 & 0.85 & 1.10 & Sp. 5 & 8 & 12.6 & 0.14 & 2.42 & 2.56 \\
\hline Macaranga sp. 2 & 11 & 14.8 & 0.63 & 1.76 & 2.39 & Sp. 5 & 8 & 10.0 & 0.09 & 1.52 & 1.60 \\
\hline Macaranga sp. 2 & 11 & 10.3 & 0.46 & 0.94 & 1.40 & Sp. 6 & 8 & 11.4 & 0.31 & 1.66 & 1.97 \\
\hline Macaranga sp. 2 & 11 & 10.3 & 0.57 & 1.00 & 1.57 & Sp. 6 & 8 & 16.0 & 0.61 & 4.12 & 4.74 \\
\hline Macaranga sp. 2 & 11 & 13.4 & 0.50 & 1.38 & 1.88 & Sp. 7 & 4 & 19.6 & 0.20 & 4.90 & 5.10 \\
\hline Macaranga sp. 3 & 2 & 18.4 & 0.58 & 4.90 & 5.47 & Sp. 8 & 8 & 11.0 & 0.74 & 1.90 & 2.64 \\
\hline Macaranga sp. 3 & 13 & 17.3 & 0.24 & 4.69 & 4.92 & Sp. 9 & 16 & 11.9 & 0.44 & 2.44 & 2.88 \\
\hline Macaranga sp. 3 & 13 & 13.7 & 0.06 & 1.57 & 1.63 & Sp. 10 & 16 & 23.2 & 0.39 & 5.09 & 5.49 \\
\hline Macaranga sp. 3 & 13 & 21.2 & 0.18 & 5.08 & 5.26 & Sp. 11 & 16 & 16.9 & 0.31 & 3.74 & 4.05 \\
\hline Macaranga sp. 4 & 14 & 26.5 & 1.23 & 14.73 & 15.96 & & & & & & \\
\hline Macaranga sp. 4 & 14 & 36.7 & 1.16 & 33.19 & 34.35 & & & & & & \\
\hline Macaranga sp. 5 & 3 & 13.0 & 0.28 & 1.85 & 2.14 & & & & & & \\
\hline Macaranga sp.? & 8 & 13.3 & 0.28 & 3.32 & 3.59 & & & & & & \\
\hline
\end{tabular}

1) GBH: Girth at breast height

2) $W_{\text {I: }}$ Dry weight of leaves

3) $W_{\mathrm{sb}}$ : Dry weight of stems and branches 